DOI:

http://e-journal.stit-islamic-village.ac.id/index.php/JECIES

\title{
MANAJEMEN OPERASIONAL DALAM PROSES PEMBELAJARAN METODE SENTRA
}

\author{
Rosita \\ Sekolah Tinggi Ilmu Tarbiyah Islamic Village Tangerang \\ Email: rosita.stit@gmail.com \\ Rica Nelvita \\ Sekolah Tinggi Ilmu Tarbiyah Islamic Village Tangerang \\ Email: ricanelvita.stit@gmail.com \\ Nurul Hikmah Mawaddah \\ Magister Manajemen Pendidikan Universitas Budi Luhur \\ Email: iik26.nhm@gmail.com
}

Received: 11 Maret, 2020.

Accepted: 20 Maret, 2020.

Published: 30 Maret, 2020

\begin{abstract}
This qualitative research was conducted with a background enriching discourse and analyzing operational management in TK / RA Sentra, namely RA Daaruttuqo. In addition, researchers want to describe the theories and facts of operational management of education in the RA / TK Daaruttuqo School which almost fulfill the management function, but with a note that is an improvement in organizing due to an unprofessional and proportional position in the realm of teaching and educational staff (administration), but in The application of RA Daaruttuqo's child development theory has fulfilled the criteria for organizing, planning and managing the curriculum in the Early Childhood learning model very well namely the Sentra method. Because the age of kindergarten should be a time of imagination so that they can present their world with words, pictures and works through their world that is playing. This study uses a descriptive qualitative approach using Spradley analysis.
\end{abstract}

Keywords: Education, Operational management, Early childhood, Qualitative, Sentra.

\begin{abstract}
ABSTRAK
Penelitian kualitatif ini dilakukan dengan latar belakang memperkaya wacana dan menganalisa manajemen operasional di $T K / R A$ Sentra, yaitu $\mathrm{R} A$ Daaruttuqo. Selain itu peneliti ingin mendeskripsikan teori dan fakta manajemen operasional pendidikan di Sekolah $\mathrm{R} A / T K$ Daaruttuqo yang hampir memenubi fungsi manajemen namun dengan catatan yaitu perbaikan dalam hal pengorganisasian dikarenakan ada posisi yang tidak professional dan proporsional dalam ranah tenaga pendidik dan kependidikan (administrasi), namun dalam aplikasi teori
\end{abstract}


perkembangan anak $\mathrm{R} A$ Daaruttuqo telah memenubi kriteria pengorganisasian, perencanaan dan pengelolaan kurikulum pada model pembelajaran Anak usia Dini dengan sangat baik yaitu metode sentra. Karena sepatutnya usia Taman Kanak. Kanak adalah masa untuk berimajinasi sehingga mereka dapat mempresentasikan dunia mereka dengan kata-kata, gambar-gambar dan karya melalui dunia mereka yaitu bermain. Penelitian ini menggunakan pendekatan kualitatif deskerptif dengan menggunakan analisis Spradley.

Kata Kunci: Pendidikan, Manajemen operasional, Anak Usia Dini, Kualitatif, Sentra.

\section{PENDAHULUAN}

Sekolah adalah upaya untuk menciptakan proses pendidikan yang ideal, dalam rangka memanusiakan manusia. Karena pendidikan adalah usaha yang dijalankan seseorang atau kelompok agar orang lain menjadi dewasa atau mencapai tingkat hidup atau penghidupan yang lebih tinggi dalam arti mental (Sudirman N., dkk, 1992: 4). Proses pendidikan sepatutnya dilakukan sejak usia dini dengan proses yang sesuai tahap perkembangannya. Berdasarkan esensi dan prinsip pedidikan. Karena pada saat ini marak pola pendidikan yang kurang mengakomodir proses perkembangan siswa, khususnya anak usia dini.

Hal ini seperti diungkap dalam Berita Satu online tahun 2016 bahwa pembelajaran PAUD yang seharusnya 80 persen membangun sikap, saat ini justru fokus pada pembelajaran baca-tulis-hitung (calistung) yang bernuansa akademik. (Sumber: https://www.beritasatu.com/2016). Hal itu pun sesuai dengan ungkapan Menteri Pendidikan dan Kebudayaan Republik Indonesia Nadiem Makarim yang menegaskan, pendidikan anak usia dini (PAUD) dilarang memaksa anak untuk membaca, menulis dan berhitung (Calistung). Pasalnya, hal tersebut akan membuat anak tidak bahagia saat berada di sekolah. (Sumber : https://www.pikiran-rakyat.com/2019). Oleh karena kehadiran sekolah ataupun PAUD seperti TK/RA/BA diharapkan menjadi jalan untuk menjadi wadah yang mengembangkan semua potensi anak bukan hanya akademik.

Taman Pendidikan Islam RA Daaruttuqo merupakan sekolah taman kanak kanak yang berdiri sejak tahun 2010 yang berlokasi di Jalan H. Oget Ketapang Rt 01/04 Kelurahan Ketapang Kecamatan Cipondoh Kota Tangerang. Taman Pendidikan Islam RA Daaruttuqo memiliki tujuan untuk mengarahkan sumber daya manusia yang berakhlak baik, potensial dan berkualitas secara islami, sehingga kecerdasan emosional, intelektual, dan spiritualnya matang serta mampu menatap dunia dengan percaya diri. Untuk mencapai tujuan tersebut RA Daaruttuqo membutuhkan kerja sama dari semua pihak, baik dari instansi pemerintah, profesional, orang tua, dan masyarakat.

Hal di atas berkaitan dengan undang-undang Republik Indonesia Nomor 20 Tahun 2003 tentang Sistem Pendidikan Nasional (Sisdiknas) pasal

JECIES: Journal of Early Childhood Islamic Education Study

Vol. 01, Nomor 01, Januari - Juni 2020 
4 ayat (6) ditetapkan bahwa "Pendidikan diselenggarakan dengan memberdayakan semua komponen masyarakat melalui peran serta dalam penyelanggaraan dan pengendalian mutu layanan pendidikan”.

RA Daaruttuqo memiliki visi sebagai Lembaga PAUD (Pendidikan Anak Usia Dini) yang bermutu, kreatif, mandiri dan memiliki daya saing di tengah masyarakat dengan berbasis iman dan takwa, sains teknologi, etika, estetika dan multiple intelegence sehingga tercipta generasi yang cerdas, kreatif, produktif, mandiri dan menjadi generasi rabbani yang handal. Sedangkan misi RA Daaruttuqo memberikan pendidikan kepada setiap anak usia dini dengan pendekatan multiple intelegence melalui kegiatan yang komprehensif, imajinatif, dan kreatif , yaitu setiap individu yang Allah SWT ciptakan telah diberikan anugerah berupa potensi, minat dan karakter yang berbeda-beda. Menciptakan program-program yang bermutu, kreatif, dan inovatif dalam rangka menghasilkan produktivitas yang selalu memenuhi tuntutan tertinggi era globalisasi. Dan memenuhi prinsip dan esensi dari nilai pendidikan.

Visi dan misi RA Daaruttuqo akan tercapai secara efektif dan efisien dengan menerapkan manajemen operasi bidang pendidikan dalam menjalankan kegiatan operasionalnya. Hal inilah yang memberi ghirah penulis untuk meneliti dan menganalisa pola manajemen operasional pada sekolah yang berbasis sentra atau wadah pendidikan yang berusaha mengakomodir seluruh aspek perkembangan siswa.

\section{METODE PENELITIAN}

Metode yang digunakan dalam penelitian ini adalah metode kualitatif. Metode kualitatif digunakan dengan tujuan untuk medeskripsikan sesuatu yang baru khususnya yang berkaitan dengan manajemen operasional dalam sekolah yang berbasis sentra. Oleh sebab itu kebutuhan utama dalam penelitian ini adalah menemukan fakta-fakta empiris secara langsung di lapangan. Penggunaan metode kualitatif sesuai dengan pengertian metode kualitatif sebagaimana dikemukakan Bogdan dan Taylor (1975: 4), bahwa metode kualitatif merupakan suatu cara dalam penelitian yang menghasilkan data deskriptif yaitu berupaya menghasilkan tulisan atau perkataan yang diucapkan serta mengamati perilaku. Oleh sebab itu peneliti sepatutnya mencatat hal yang dilihat dan didengar di lapangan maka hal tersebut merupakan hasil yang dapat dijadikan data konkrit dalam penelitian ini.

\section{HASIL DAN PEMBAHASAN}

\section{A. Dasar Teoritis}

\section{Manajemen Operasional Dalam Pendidikan}

Kata manajemen menurut Sudarwan Danim dan Suparno berasal dari Bahasa prancis kuno yaitu management yang berarti seni melaksanakan dan 
mengatur (2009 : 3). Menurut Henrifayol dalam Gerald Ngugikimani kata to manage diartikan meramal dan merencanakan (to manage is forecasting and plan) (2005 : 16). Sedangkan menurut Husaini Usman kata manajemen dari Bahasa latin yaitu asal kata manus yang berarti tangan dan agere yang berarti melakukan, kata-kata itu digabung menjadi kata kerja manager berarti menangani dan manager diterjemahkan kedalam Bahasa inggris dalam bentuk kata kerja to manage berarti mengurusi, dengan kata benda management dan manager untuk orang yang melakukan kegiatan manajemen (2004 : 5). Dan menurut Hasan alwi (2002 : 708) dalam kamus besar Bahasa Indonesia, manajemen diartikan sebagai pemberdaya sumber daya secara efektif untuk mencapai sasaran. Jadi secara etimologi manajemen dapat diartikan sebagai upaya mengelola.

Adapun secara terminologi menurut beberapa teori diantaranya, Keitner dalam Agus Wibowo (2013 : 29) menyatakan manajemen adalah suatu proses pemecahan masalah untuk tujuan organisasi melalui penggunaan sumber daya yang efisien dan efektif di lingkungan organisasi yang terus berubah-ubah. Sedangkan menurut Van fleet dan Peterson mengartikan manajemen dengan seperangkat kegiatan yang diarakan pada pemanfaatan sumber daya secara efisien dan efektif untuk mencapai tujuan yang lebih. Dan menurut Ali Imron (2011 : 5) Manajemen merupakan suatu kegiatan yang dilakukan secara bersama-sama oleh dua orang atau lebih yang didasarkan atas aturan tertentu dalam rangka mencapai suatu tujuan. Dua orang atau lebih yang bekerja sama tersebut diikat oleh atura-aturan tertentu, ada yang berfungsi sebagai manajer dan ada yang dimanajerinya. Pada saat bekerja, baik yang menjadi manajer dan yang dimanajerinya dapat mendayagunakan berbagai sarana dan prasarana yang tersedia. Adapun Menurut Handoko (2009:8), Manajemen adalah proses perencanaan, pengorganisaian, pengarahan, dan pengawasan usaha-usaha para anggota oraganisasi dan penggunaan sumber daya-sumber daya organisasi lainnya agar mencapai tujuan organisasi yang telah ditetapkan. Menurut Hikmat (2009:11) menyatakan bahwa manajemen adalah ilmu dan seni mengatur proses pemanfaatan sumber daya manusia secara efektif yang didukung oleh sumber-sumber lainnya dalam suatu organisasi untuk mencapai tujuan tertentu, seperti penedidikan.

Manajemen Pendidikan didefinisikan sebagai seni dan ilmu mengelola sumber daya pendidikan untuk mewujudkan suasana belajar dan proses pembelajaran agar peserta didik secara aktif mengembangkan potensi dirinya untuk memiliki kekuatan spiritual keagamaan, pengendalian diri, kepribadian, kecerdasan akhlak mulia, serta keterampilan yang diperlukan dirinya, masyarakat, bangsa dan negara. Dan menurut Husaini Usman (2004 : 12) manajemen pendidikan dapat didefinisikan sebagai proses perencanaan, 
perorganisasian, pengarahan dan pengendalian sumber daya pendidikan untuk mencapai tujuan pendidikan secara efektif, efisien mandiri dan akuntabel.

Menurut Purwanto manajemen Pendidikan adalah semua kegiatan sekolah dari yang meliputi usaha besar seperti perumusan aturan, pengaran usaha-usaha besar, koordinasi, konsultasi, korespondensi, kontrol perlengkapan, dan seterusnya sampai usaha-usaha kecil dan sederhana. Namun setiap proses pengorganisasian harus ada proses manajerial yang baik. Sehingga tercipta manajemen pendidikan yang secara operasional berjalan professional dan proporsional.

Manajemen operasional merupakan aktivitas pengelolaan sumber daya yang di tujukan kepada produksi dan pengiriman produk dan jasa. Jika diterapkan dalam bidang pendidikan, manajemen operasional berperan penting dalam mewujudkan sistem pendidikan yang bermutu dan berkelanjutan. Dikatakan penting karena proses penataan sumber daya pendidikan (pegelolaan tenaga kependidikan, kurikulum, dan pembelajaran, keuangan, sarana dan prasarana pendidikan, serta keterlibatan secara terpadu dan simultan antara pemerintah, sekolah dan masyarakat perlu diatur secara professional). Dengan demikian, manajemen pendidikan yang professional merupakan kunci utama dalam membangun pendidikan nasional. Namun hal tersebut tentu akan terlaksana apabila realita dan harapan dari suatu teori seiring sejalan.

Dengan demikian manajemen operasional dalam pendidikan yaitu : proses perencanaan, pengorganisaian, pengarahan, dan pengawasan serta usaha-usaha dalam semua kegiatan sekolah, dari yang meliputi usaha besar seperti perumusan aturan, penganggaran usaha-usaha besar, koordinasi, konsultasi, korespondensi, kontrol perlengkapan, sampai usaha-usaha kecil dan sederhana, sehingga terjadi proses penataan sumber daya pendidikan (pengelolaan tenaga kependidikan, kurikulum, dan pembelajaran, keuangan, sarana dan prasarana pendidikan, secara professional dan proporsional.

\section{Perkembangan Anak Usia Dini}

Perkembangan anak usia dini adalah masa penting (golden age) dalam periode kehidupan manusia. Karena masa itu adalah masa anak menyerap informasi bagaikan sebuah sponse. Baik dari psikomotorik, afekti (sikap) ataupun kognitif (daya pikir). Dalam perkembangan kognitif, menurut Santrock (2007: 252) anak usia Taman Kanak Kanak berada pada tahap praoperasional, anak mulai mempresentasikan dunia mereka dengan kata-kata, bayangan dan gambar-gambar. Anak mulai berfikir simbolik, pemikiranpemikiran mental muncul, egosentrisme tumbuh, dan keyakinan magis mulai terkonstruksi. Pada tahap praoperasional dapat dibagi dalam sub-sub tahap, yaitu sub tahapan fungsi simbolik dan sub tahapan pemikiran intuitif. Sub 
tahap fungsi simbolik anatara usia 2 sampai 4 tahun. Dalam sub tahap ini anak mulai dapat menggambarkan secara mental sebuah objek yang tidak ada seperti orang, rumah, mobi, awan dan sebagainya. Sedangkan sub tahap pemikiran intuitif terjadi anatar usia 4 sampai 7 tahun. Anak mulai mempraktikan penalaran primitif dan ingin mengetahui jawaban dari berbagai pertanyaan. Namun anak masih berfikir secara sentralisasi, yaitu pemusatan perhatian pada suatu karakteristik dan pengabaian karakteristik lain. Cara berfikir anak pada tahap ini masih irreversible (tidak dapat di balik). Anak belum mampu meniadakan suatu tindakan dari arah sebaliknya. Pada tahap ini anak sering bertanya dengan pertanyaan "mengapa", hal ini merupakan tanda bahwa dalam diri anak mulai muncul minat dalam memikirkan dan menemukan hakekat akan sesuatu. Hal ini berkaitan dengan tanggung jawab otak manusia terhadap pengaturan seluruh badan dan pemikiran manusia. Oleh karena itu terdapat kaitan erat antara otak dan pemikiran.

Otak adalah pusat yang menentukan gerakan dan berpikir manusia. Menurut Paul Maclean dalam Dave menjelaskan bahwa otak manusia terbagi menjadi 3 yaitu otak reptil, sistim limbik dan neokorteks, teori ini sering dikenal dengan teori otak triune (Dave Meier, 2002: 83). Perkembangan otak anak yang sedang tumbuh menurut Agus Surono melalui tiga tahapan, mulai dari otak primitif (action brain), otak limbik (feelingbrain), dan akhirnya ke neocortex (atau disebut juga thought brain,otak pikir) :( http://www.Tiga tahap perkembangan otak- IntisariOnline.htm). Meski saling berkaitan, ketiganya punya fungsi sendiri-sendiri, yaitu :

a. Otak primitif mengatur fisik kita untuk bertahan hidup, mengelolagerak refleks, mengendalikan gerak motorik, memantau fungsitubuh, dan memproses informasi yang masuk dari pancaindera.Saat menghadapi ancaman atau keadaan bahaya, bersama denganotak limbik, otak primitif menyiapkan reaksi "hadapi atau lari"(fight or flight response) bagi tubuh.

b. Otak limbik memproses emosi seperti rasa suka dan tidak suka,cinta dan benci. Otak ini sebagai penghubung otak pikir dan otak primitif. Maksudnya, otak primitif dapat diperintah mengikuti kehendak otak pikir, di saat lain otak pikir dapat "dikunci" untuk tidak melayani otak limbik dan primitif selama keadaan darurat,yang nyata maupun yang tidak. Sedangkan otak pikir, yang merupakan bentuk daya pikir tertinggi dan bagian otak yang paling objektif, menerima masukan dari otak primitif dan otak limbik. Namun, ia butuh waktu lebih banyak untuk memproses informasi, termasuk image, dari otak primitif dan otak limbik. 
c. Otak pikir juga merupakan tempat bergabungnya pengalaman,ingatan, perasaan, dan kemampuan berpikir untuk melahirkan gagasan dan tindakan.

Myelinasi saraf otak berlangsung secara berurutan, mulai dariotak primitif, otak limbik, dan otak pikir. Jalur syaraf yang makin sering digunakan membuat myelin makin menebal. Makin tebal myelin, makin cepat impuls syaraf atau perjalanan sinyal sepanjang "urat" syaraf. Karena itu, anak yang sedang tumbuh dianjurkan menerima masukan dari lingkungannya sesuai dengan perkembangannya.

\section{Pendidikan Anak Metode Sentra}

Pendidikan pada anak usia dini adalah adalah pendidikan yang sangat penting bagi anak di kemudian hari. Kualitas pengalaman yang diperoleh anak di masa usia dini akan menjadikanlebih bermakna untuk mencapai masa depanya. Secara alami anak-anak adalah pembelajar yang aktif. Mereka sangat menyenangi melakukan pengamatan, eksplorasi, berimajinasi, menemukan, melakukan penyelidikan, mengumpulkan informasi serta berbagi pengalaman. Pengalaman belajar pada masa usia dini dapat dapat ditingkatkan kepada yang lebih tinggi melalui kepedulian orang tua, guru pada anak, agar anak dapat ditingkatkan supaya terbentuk sikap positif terhadap belajar.

Belajar dalam penerapan pembelajaran bias dilakukan dengan berbagai model. Istilah model diartikan sebagai kerangka konseptual yang digunakan sebagai pedoman dalam melakukan suatu kegiatan pembelajaran (Winata Putra : 2001). Dengan demikian model pembelajaran adalah kerangka konseptual (yang melandasi teori belajar dan pembelajaran) yang menggambarkan prosedur sistematis dalam mengorganisasikan pengalaman belajar untuk mencapai tujuan belajar tertentu dan berfungsi sebagai pedoman bagi perancang dan para pengajar dalam merancang, mempersiapkan dan melaksanakan aktivitas instruksional.

Pengembangan model pembelajaran sangat diperlukan dalam memperkenalkan dan mengembangkan pembelajaran di Taman Kanak-kanak sebagai model bagi guru-guru untuk membuat prosedur sistematis dalam mengorganisasikan pengalaman belajar untuk mencapai tujuan belajar tertentu dan berfungsi sebagai pedoman bagi perancang dan para pengajar dalam merancang, mempersiapkan dan melaksanakan aktivitas instruksional. Sehingga pembentukan konsep-konsep yang dipelajari lebih alamiah dan pemahaman anak menjadi lebih meningkat dan lebih bermakna.

Menurut Yudistira Massardi Pembelajaran model sentra ini berkaitan dengan sejarah metode sentra di Indonesia. (2011:118), yaitu berawal dengan program "Beyond Centres And Circle Times (BCCT). Metode Sentra atau Beyond Centers and Circle Time (BCCT) adalah model kurikulum pendidikan 
anak usia dini yang dirancang oleh Pamela C. Phelps, Ph.D., seorang pendidik yang telah 40 tahun lebih menekuni bidang pendidikan anak usia dini. Phelps mengembangkan BCCT di lembaga pendidikan dan penelitian Creative Center for Childhood Research and Training (CCCRT), Tallahassee, Florida, Amerika Serikat. Di dalam lembaga itu, ia mengelola Creative Pre-School, yang sejak tahun 1989 ditetapkan sebagai sebuah model negara bagian dan kemudian nasional sebagai sekolah usia dini inklusif, yang dapat melayani anak-anak berkebutuhan khusus.

Metode Sentra atau BCCT dirancang oleh Sara Smilanski dan Charles Wolfgang untuk memenuhi kebutuhan tiga jenis main sebagai model belajar anak usia dini. Ketiga jenis main yang dibutuhkan anak usia dini itu adalah main sensorimotor, main pembangunan, dan main peran. Pemenuhan kebutuhan ketiga jenis main dijalankan secara terpadu dan terukur sesuai dengan tahaptahap perkembangan anak. Ketiga jenis main itu disediakan di sentra-sentra.

Sentra-sentra merupakan unit-unit arena bermain yang berisi bermacam-macam alat permainan edukatif (APE). Dengan pengelompokan APE-APE dan pengorganisasian aktivitas-aktivitas mainnya secara spesifik, masing-masing sentra memiliki penekanan tujuan yang berbeda-beda dalam membangun aspek-aspek tumbuh-kembang anak. Namun demikian, setiap sentra pada prinsipnya menyediakan kesempatan anak untuk melakukan ketiga jenis main. Pembangunan kemampuan itu mencakup keenam aspek yaitu psikomotor, afeksi, kognisi, sosial, bahasa, dan estetika.

Dalam merencanakan pengalaman main, guru memperhatikan dengan teliti kecukupan jumlah aktivitas main (densitas) dan lama proses bermain (intensitas). Pengalaman-pengalaman main dirancang dalam rangka mendukung anak melalui tahap-tahap perkembangannya secara sehat dan lancar.Kegiatan sentra pun tak terlepas dari tema sebagai payung dari setiap kegiatan di sentra. Pijakan (Scaffolding) pun menjadi nilai ukur dalam keberhasilan pembelajaran dengan metode sentra ini. Ada 4 pijakan yang diterapkan dalam kegiatan bermain sentra yaitu : pijakan lingkungan, pijakan sebelum main, pijakan individu dan pijakan setelah main.

Dengan demikian pendidikan anak usia dini dengan model pembelajaran sentra adalah kegiatan yang mengembangkan sistem kerja otak anak berdasarkan usia, perkembangan, kebutuhan anak melalui bermain sebagai model pembelajaran.

\section{B. Analisis dan Pembahasan}

Hasil yang didapatkan mengenai manajemen operasional dalam proses pembelajaran metode sentra di RA Daaruttuqo Ketapang Cipondoh Tangerang Banten. Tepatnya dalam Proses perencanaan, pengorganisaian, pengarahan, dan pengawasan serta usaha-usaha dalam semua kegiatan sekolah,

JECIES: Journal of Early Childhood Islamic Education Study

Vol. 01, Nomor 01, Januari - Juni 2020 
dari yang meliputi usaha besar seperti perumusan aturan, penganggaran usahausaha besar, koordinasi, konsultasi, korespondensi, kontrol perlengkapan, sampai usaha-usaha kecil dan sederhana, sehingga terjadi proses penataan sumber daya pendidikan (pegelolaan tenaga kependidikan, kurikulum, dan pembelajaran, keuangan, sarana dan prasarana pendidikan, secara professional dan proporsional. Dibahas dalam 5 pokok bahasan yaitu:

\section{Pegelolaan tenaga pendidik dan kependidikan:}

Dalam Permen 58 tahun 2009 kategori tenaga kependidikan dan tenaga pendidik memiliki fungsi dan posisi yang berbeda, tenaga kependidikan diantaranya adalah: guru, pendamping guru dan pengasuh PAUD. Sedangkan tenaga kependidikan adalah Pengawas/Penilik, Kepala PAUD dan pengelola PAUD serta Administrasi PAUD. Dari kedudukan dan fungsi mereka berbeda. Namun di RA Daaruttuqo fungsi itu belum terorganisir dengan baik, hal ini terlihat dari admintrasi yang masih dipegang oleh salah seorang guru dan kepala sekolah. Sehingga bisa dikatakan dalam pengelolalan tenaga pendidik dan kependidikan secara fungsi belum memenuhi nilai professional dan proporsional (kurang baik).

\section{Kurikulum:}

Peningkatan kegiatan belajar mengajar terkait dengan kurikulum dan diaplikasikan dalam model pembelajaran. Hal ini dapat terwujud secara proporsional apabila mengikuti aturan yang ada dan teraplikasi dengan baik. RA Daaruttuqo telah melakukan dan mengaplikasikan model pembelajaran yang sesuai dengan perkembangan anak yaitu Kegiatan yang mengembangkan sistem kerja otak anak berdasarkan usia, perkembangan, kebutuhan anak melalui bermain sebagai model pembelajaran, hal ini sesuai dengan sejalan dengan tujuan pendidikan yang dirumuskan oleh UNESCO yang menyatakan bahwa pendidikan adalah serangkaian aktivitas untuk menanamkan kecakapan hidup (life skills), kecakapan untuk bertindak (to do), kecakapan untuk hidup (to be), kecakapan belajar (to learn), dan kecakapan hidup bersama (live together).

Selain itu Yayasan RA Daaruttuqo untuk mendukung proses pembelajaran yang sesuai kebutuhan anak dengan memberikan peluang guruguru untuk mengikuti penataran-penataran yang diselenggarakan oleh internal yayasan atau pun instansi yang berwenang, diantaranya :

a. Pelatihan model pembelajaran metode sentra yang berkesinambungan setiap tahun.

b. Pengembangan materi ajar membaca al-Qur'an

c. Pengembangan kurikulum oleh dinas atau pun Kementrian Pendidikan Nasional, dan lain sebagainya. 
Sehingga dapat disimpulkan dalam hal ini kurikulum serta pengembangannya yang digunakan RA Daaruttuqo "sangat baik" karena sesuai dengan ekspektasi dan harapan ideal pendidikan anak usia dini.

\section{Pembelajaran:}

Proses pembelajaran yang diterapkan di RA Daaruttuqo adalah pembelajaran sentra, yaitu sentra bahan alam, sentra persiapan, sentra imtaq dan sentra Balok. Dalam kegiatan sentra memiliki 4 pijakan yaitu pijakan lingkungan, pijakan sebelum main, pijakan individu dan pijakan setelah main. Sehingga keberhasilan model pembelajaran sentra sesuai dengan kebutuhan perkembangan anak yang mencakup keenam aspek yaitu psikomotor, afeksi, kognisi, sosial, bahasa, dan estetika. Karena pembelajaran sentra adalah kumpulan dari berbagai teori yang mengedepankan teori perkembangan anak. Hal ini sesuai dengan ungkapan Santrock (2007: 252) bahwa anak usia Taman Kanak Kanak berada pada tahap pra-operasional, anak mulai mempresentasikan dunia mereka dengan kata-kata, bayangan dan gambargambar. Sehingga dapat disimpulkan dalam hal ini pembelajaran yang digunakan RA Daaruttuqo "sangat baik".

\section{Keuangan}

Dalam hal keuangan dan administrasi sekolah, RA Daaruttuqo secara aplikasi semua terlaksana dan sesuai dengan standar kepuasaan yang dipelihatkan guru, melalui gaji dan tunjangan yang diberikan oleh pihak sekolah sebagai kompensasi dan usaha mendidik oleh guru kepada siswanya. Namun secara operasional belum terorganisir sesuai posisinya, hal ini terlihat dari adminitrasi yang masih dipegang oleh salah seorang guru dan kepala sekolah. Sehingga bisa dikatakan dalam pengelolalan tenaga pendidik dan kependidikan secara fungsi belum memenuhi nilai professional dan proporsional (belum cukup baik) karena masih ada yang memiliki tugas ganda. Dan tidak sesuai dengan Permen 58 tahun 2009 kategori tenaga kependidikan dan tenaga pendidik yang memiliki fungsi dan posisi yang berbeda.

\section{Sarana dan prasarana pendidikan :}

Berdasarkan ungkapan Santrock (2007: 252) bahwa anak usia Taman Kanak Kanak berada pada tahap pra-operasional, anak mulai mempresentasikan dunia mereka dan belajar dari hal yang konkrit. Maka sarana dan prasarana adalah hal yang mendukung proses dan kelancaran pembelajaran seperti : ruang kelas, tempat bermain, alat permainan di sentra yang disesuaikan dengan kebutuhan dan perkembangan anak. Dengan demikian di RA Daaruttuqo penyediaan sarana dan prasarana bisa dikatakan baik karena pihak sekolah berusaha menyediakan alat peraga serta alat permainan dan fasilitas

JECIES: Journal of Early Childhood Islamic Education Study Vol. 01, Nomor 01, Januari - Juni 2020 
"cukup baik". Hal ini terlihat dari tersedianya sarana bermain outdoor dan indoor untuk anak meskipun belum lengkap, namun sudah memenuhi kebutuhan motorik anak usia dini.

Berdasarkan teori dan fakta manajemen operasional pendidikan Sekolah RA/TK Daaruttuqo jika dijelaskan dalam grafik adalah sebagai berikut:

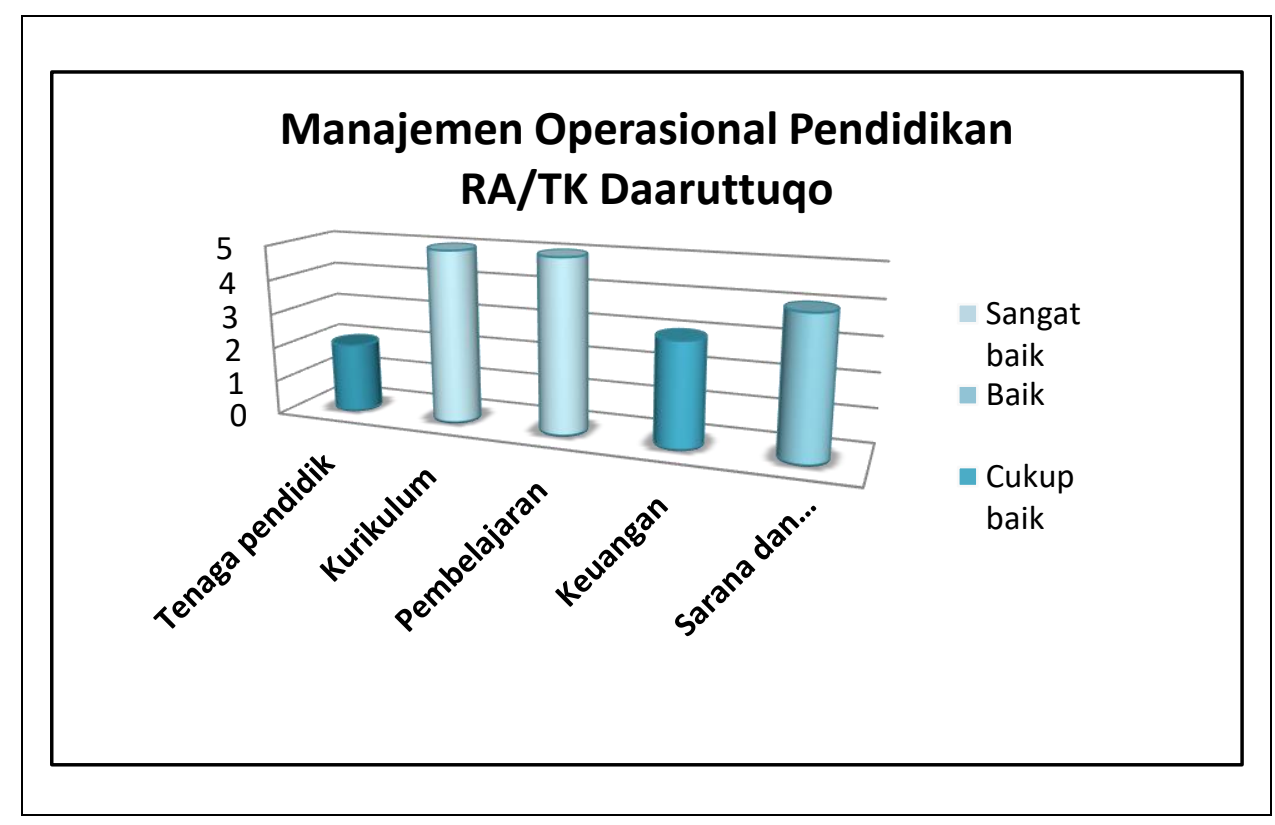

Gambar 1. Grafik manajemen operasional pendidikan Sekolah RA/TK

\section{Daaruttuqo}

Sehingga apabila diuraikan manajemen operasional RA Daaruttuqo sebagai model sekolah dengan metode sentra sangat baik dari aspek pendidikan, kurikulum, pembelajaran dan sarana dan prasarana. Namun memiliki catatan yang kurang baik dalam hal pengorganisasian dikarenakan ada posisi yang tidak professional dan proporsional dalam ranah tenaga pendidik dan kependidikan (administrasi).

\section{KESIMPULAN}

Berdasarkan teori dan fakta manajemen operasional pendidikan di Sekolah RA/TK Daaruttuqo hampir memenuhi fungsi manajemen namun dengan catatan yaitu perbaikan dalam hal pengorganisasian dikarenakan ada posisi yang tidak professional dan proporsional dalam ranah tenaga pendidik dan kependidikan (administrasi). Berdasarkan teori perkembangan anak RA

JECIES: Journal of Early Childhood Islamic Education Study 
Daaruttuqo telah memenuhi kriteria pengorganisasian, perencanaan dan pengelolaan kurikulum pada model pembelajaran Anak usia Dini dengan sangat baik yaitu metode sentra, dan tentunya patut dipertahankan serta selalu dikembangkan. Dengan demikian mutu secara "administrasi" RA Daaruttuqo sebagai model pendidikan metode sentra secara keseluruhan memiliki kesamaan dengan RA/TK konvensional atau bukan model pembelajaran metode sentra, meskipun di RA Daaruttuqo memiliki catatan yang harus di perbaiki dalam aspek fungsi administrasi. Tapi dengan "mutu kurikulum dan pembelajaran" Sekolah RA/TK Daaruttuqo bisa dikatakan lebih baik jika dibandingkan sekolah yang menjalankan metode konvensional yang mengedepankan nilai akademik atau menekankan calistung (baca, tulis, hitung), karena ini tidak sesuai dengan aspek perkembangan anak yang sepatutnya usia Taman Kanak Kanak adalah masa untuk berimajinasi sehingga mereka dapat mempresentasikan dunia mereka dengan kata-kata, gambar-gambar dan karya melalui dunia mereka yaitu bermain.

\section{REFERENSI}

Auerbacch,Stevanne, (2007) Smart Play Smart Toys. Jakarta: PT Buana Ilmu Populer

Alwi,Hasan,dkk, (2002) Kamus Besar Bahasa Indonesia Indonesia. Jakarta: Balai Pustaka

Agus Surono. (2011) Tiga Tahap Perkembangan Otak. http://www.Tiga tahap Perkembangan Otak- Intisari Online.htm [Tiga Tahap Perkembangan Otak]

Bogdan, Robert C and Steven J. Taylor, (1975) Introduction to Qualitative Research Method New York: John Willey and Son

Danim, Sudarwan dan Suparno, (2009) Manajemen dan Kepemimpinan Transformasional kepala sekolah. Jakarta: Rineka Cipta

https://www.beritasatu.com/2016

https://www.pikiran-rakyat.com/2019).

Imron, Ali, (2011) Manajemen Peserta Didik Berbasis Sekolah. Jakarta: Bumi Aksara 
Masardi, Yudistira dan Sisca Y, (2012) Pendidikan Karakter Dengan Metode Sentra, Penerbit: Media Pustaka Sentra, Bekasi

Ngugikimani, Gerald, (2005), Educational Management, (South Africa: Africa Virtual University, tt)

Usman, Husaini, (2004), Manajementeori, Praktik, dan Riset Pendidikan(Jakarta: BumiAksara)

Wibowo, Agus, (2013) Manajemen Pendidikan Karakter Di Sekolah: Konsep Dan Praktik Implementasi. Yogyakarta: Pustaka Pelajar 